\title{
POST-FIRE CHANGES IN THE BIOLOGICAL PROPERTIES OF THE BROWN SOILS IN THE UTRISH STATE NATURE RESERVE (RUSSIA)
}

\author{
Kamil Sh. Kazeev ${ }^{1, *}$, Tatyana A. Poltoratskaya ${ }^{1}$, Anastasia S. Yakimova ${ }^{1}$, \\ Mary Yu. Odobashyan ${ }^{1}$, Aslan K. Shkhapatsev ${ }^{2}$, Sergey I. Kolesnikov ${ }^{1}$ \\ ${ }^{1}$ Southern Federal University, Russia \\ *e-mail: kamil_kazeev@mail.ru \\ ${ }^{2}$ Maykop State Technological University, Russia \\ e-mail:6620607-11@mail.ru
}

Received: 03.02.2019. Revised: 28.04.2019. Accepted: 23.07.2019.

\begin{abstract}
The unique ecosystems of the Abraus peninsula on the Caucasian Black Sea coast persisted in the Utrish State Nature Reserve (Russia), are represented by dry Eastern Mediterranean subtropics with a large number of endemics and relics that have been persisted from the Tertiary period. This is one of the few places in Russia where juniper pistachio (Pistacia atlantica, Juniperus excelsa, J. foetidissima, J. oxycedrus) woodlands grow. In 2016-2018, a study was conducted on the content of the biological properties of brown soils in two areas of the Abraus peninsula. The main focus is on the monitoring of Vodopadnaya shchel' on the Utrish State Nature Reserve monitoring site, located in the post-fire area of juniper woodland (Pistacia atlantica, Juniperus excelsa, $J$. foetidissima, J. oxycedrus) at an altitude of 110-140 m a.s.l. on the southern spurs of the Ridge Navagir. The fire happened in 2009. Additionally, in April 2018, the site of the burnt area of 2013 was investigated in the immediate vicinity of the Sukhaya shchel' of the Utrish State Nature Reserve. The area of the burnt site was several hectares including violation of terrestrial vegetation and changes in the ecological state of the soil. We have demonstrated that brown soils are rare for Russia (Cromic Cambisol and Cromi-Leptic Luvisol according to the WRB international classification). But these are widespread in most parts of the Abraus peninsula, including the Utrish State Nature Reserve. The main features of brown soils include the brown colour of the soil profile; intense textural lining of the middle part of the soil profile; eluvial-illuvial type of decarbonisation closed to neutral reaction of the environment; soil richness with elements of mineral nutrition. The studied soils in the Utrish State Nature Reserve are characterised by higher stoniness and rubble, no carbonate growths, fragmentation of the forest floor due to the low-mountain dissected relief of the territory. We have studied the ecological and biological properties of these soils in response to fire (e.g. temperature, moisture, soil bulk density, organic carbon and carbonate content, bacteria abundance, catalase, peroxidase, dehydrogenase, and invertase activities). In the grass-shrub stage, the restorative succession was in both burnt areas. The fire had a significant effect on the ecological and biological properties of brown soils 5-9 years after the fire impact. Many of the biological properties of post-fire soils differed significantly in comparison with the properties of control areas of juniper light forest. The organic carbon content and biological activity of post-fire soils as a whole are reduced as compared with the soils of control areas of juniper light forest. In this case, a high variation of the biological parameters of the soil was noted in different parts of the same burnt area. The variation is associated both with the peculiarities of the mountain relief, and with the nature of the vegetation, which forms refugia different in the number of plant residues. The rate of carbon dioxide production in the surface horizons of the burnt area soil is more than 2 times lower than the values in control areas. Five years after the fire, the post-fire soil of the Sukhaya shchel' area contained almost half of the humus content at the $5 \mathrm{~cm}$ surface layer compared to the soil of the control area of juniper woodlands. At a depth of 15-25 cm, the difference between the soils areas remained at the same level as for the upper horizons. Thus, we demonstrated a significant effect of fires on the biological parameters of the subtropical soils in the Utrish State Nature Reserve, which has been persisted for many years.
\end{abstract}

Key words: biological activity, extracellular enzyme activities, pyrogenic effect, soil organic carbon, wildfire

Fires are frequent phenomena that occur both naturally and anthropogenically. Fires affect all components of ecosystems. The development of the forest stand, species diversity and plant population density can be reduced radically (Kuleshova et al., 1996). In general, a decrease in the proportion of grass in the ground cover, the dominance of mosses, lichens, shrubs occurs in forest areas repeatedly exposed to fires. The significant role of fires in forest renewal in the forest zone of Russia has been established (Khanina et al., 2018).
Soil characteristics are found to be less sensitive to wildfires than the aboveground vegetation (Pingree \& DeLuca, 2018). However, wildfires make big changes in the microflora and diversity of the soil fauna, soil chemical composition, content of organic matter and nutrients. After the fire influence, soil compaction occurs, water permeability deteriorates, the structure and $\mathrm{pH}$ change, mineralised organic matter losses, nitrification decreases (Magzanova \& Khiyalieva, 2013; Adkins et al., 2019). Fires lead to changes in the geochemical 
characteristics of ecosystems due to the removal in smoke form and the subsequent leaching of nutrients from the soil and changes in the hydrothermal regime. The changes in abiotic conditions inevitably lead to the transformation of the qualities of ecological niches in the burnt areas, changes in the environment connectivity and the spatial structure of the soil cover (Wardle et al., 2008). According to the impact degree in areas with soils of loamsand structure, the fire influence on soils is much higher than the agriculture influence. A change in the composition of the ground cover determines a change in the nature of humus accumulation (i.e. humus formation). Valkov et al. (1996) revealed that the stumps of stubble and straw adversely affect the humus status in chernozem. Even one-year observations reveal a tendency to decrease the total and water-soluble humus content due to humic and fulvic acids. This leads to an increase in the proportion of non-hydrolysable organic matter residue.

During the fire influence, both thermal factors and toxic products of combustion have a negative effect on biota (Valkov et al., 1996). Fires have a negative impact on the structure and metabolic activity of the microbial community of the post-fire soil of pine (Pinus sylvestris L.) forests (Maksimova et al., 2017). The biological postfire processes increase with a low intensity of fires and decrease with a high intensity (Valkov et al., 1996). A soil quality assessment should identify target threats, functions, and ecosystem services (Bünemann et al., 2018). The most common parameters are organic matter, $\mathrm{pH}$, available phosphorus and water supply. Biological and biochemical parameters are underrepresented, but they have a high potential. The soil activity of enzymes is important in assessing the soil quality and diagnosing their ecological status (Hugh, 2012; Burns et al., 2013; Dose et al., 2015; Raiesi \& Salek-Gilani, 2018). The fire-induced effect has a significant effect on the enzyme activity of the soil (Odabashyan et al., 2017; Lucas-Borja et al., 2018; Fernández-García et al., 2019; Moya et al., 2019). Therefore, the soil activity of enzymes can be considered as potential parameter of the fire-induced effects in soils.

The renewal of the burnt areas takes a long time and depends on the strength of the fire-induced effects (Alcañiz et al., 2016; Francos et al., 2018). Fires can have long-term implications for carbon accumulation in biomass and the recovery ability of forests after disturbances (Adkins et al., 2019). The authors showed a significance of the fire-in- duced effect degree on the general soil condition in the pine (Pinus pinaster Aiton) forests of Spain, three years after the fire impact. The content of available phosphorus increased with an increasing degree of the fire-induced effect in acidic soils of the Pinus pinaster ecosystem (Fernández-García et al., 2019). Even for a long time after the fire impact ( $>50$ years), the level of soil quality in post-fire forest areas did not reach the one in unburnt areas in the Mediterranean Region (Spanish Mallorca) (Lucas-Borja et al., 2018). These data indicate a significant soil degradation caused by wildfire.

Our study aimed to determine the post-fire changes in the biological activity of the brown subtropical soils of the Abraus peninsula. The largest areas of brown soils cover Western and Central Europe, the east coast of America and East Asia. In East Asia, these soils are especially typical in Japan, Korea, China, further in Eastern Australia and New Zealand. The impact of wildfire and prescribed fire on the various soil parameters is of high interest around the world (Alcañiz et al., 2016; Fonseca et al., 2017; Girona-García et al., 2018; Hobley et al., 2017; Francos et al., 2018; Moya et al., 2019).

\section{Material and Methods}

The Abraus Peninsula is bounded by the Tsemes Bay in the southeast, and by the intact remnant of the Navagir Ridge in the northeast. This range protects Novorossiysk and Gelendzhik from northern winds. This is the northernmost region of dry subtropics in the North Caucasus. It is characterised by a dry subtropic climate with mild, wet, almost snowless winters and dry summers. The westernmost part of the Caucasus has round shapes and small elevations (up to 500 $1000 \mathrm{~m}$ ). This mountain system is not an obstacle to the movement of wet western air masses, which is the cause of the climate aridity (annual precipitation of $500-600 \mathrm{~mm}$ ).

The unique ecosystems of the Abraus Peninsula, persisted in the Utrish State Nature Reserve, are represented by dry eastern Mediterranean subtropics with a large number of endemics and relics remained since the tertiary period. In Russia, this is one of the few areas, where juniper pistachio (Pistacia atlantica Desf., Juniperus excelsa M. Bieb., J. foetidissima Willd., J. oxycedrus L.) woodlands occur. The floristic list of the Utrish State Nature Reserve includes 914 vascular plant species (Demina et al., 2015). The vegetation contains relict representatives of the dry Mediterranean flora. For example, forest ecosystems include addition- 
ally oak (Quercus petraea (Matt.) Liebl., Q. pubensens Willd.), hornbeam (Carpinus betulus L., C. orientalis Mill.) and Crimean pine (Pinus nigra subsp. pallasiana (Lamb.) Holmboe), various junipers (Juniperus excelsa, J. foetidissima, J. oxycedrus), xerophytic shrubs (Paliurus spina-christi Mill., Rhus spp., Lonicera caprifolium L., Cotinus coggygria Scop., etc.), Pitsundskaya pine (Pinus brutia var. pityusa (Steven) Silba) and pistachio (Pistacia atlantica).

In 2012-2016, a monitoring investigation of the flora, fauna and soils of the Abraus peninsula were carried out. The distribution of biota and soils was found to be dependent on location, topography, rocks, and the level of anthropogenic disturbance (Valkov et al., 2007; Kutrovsky et al., 2008; Kazeev et al., 2013). Brown soils are widespread in most parts of the Abraus peninsula, including the Utrish State Nature Reserve. The main features of brown soils include the brown colour of the soil profile, intense textural lining of the middle part (in horizon $\mathrm{Bt}$ ) of the soil profile, eluvial-illuvial decarbonisation type, close to neutral reaction of the environment, soil richness with elements of mineral nutrition. Field studies have been carried out in 2016 and 2018 on two sites of the Abraus peninsula (Fig. 1).
Study site 1 was a post-fire juniper (Juniperus excelsa, J. foetidissima, J. oxycedrus) woodland at an altitude of $110-140 \mathrm{~m}$ a.s.l. at the Vodopadnaya shchel' in the Utrish State Nature Reserve (southern spurs of the Ridge Navagir) (Fig. 2). The wildfire occurred in 2009. It destructed the vegetation cover and changed the ecological status of the soil. In 2016, five soil profiles and 10 pits were established. In 2018, three soil cuts were established in the post-fire area and three more on the control site located in Juniperus woodland. The characteristics of study site 1 is presented in Table 1 .

Study site 2 was a burnt area at the middle part of the seaside slope nearby the Sukhaya shchel' (Fig. 2). In 2013, the wood-shrub vegetation of juniper woodlands was damaged by wildfire in a total area of several hectares. Study site 2 was located on a steep, long seaside slope with a high degree of rockiness $(30 \%$ of stones in a layer of $0-10$ $\mathrm{cm})$. The control area of Juniperus woodland was investigated $200 \mathrm{~m}$ from study site 1 .

On both study sites, the soils were brown leached stony on eluvium sandstones (Cromic Cambisol and Cromi-Leptic Luvisol according to the WRB international classification). The thickness of the brown layer was $25-30 \mathrm{~cm}$.

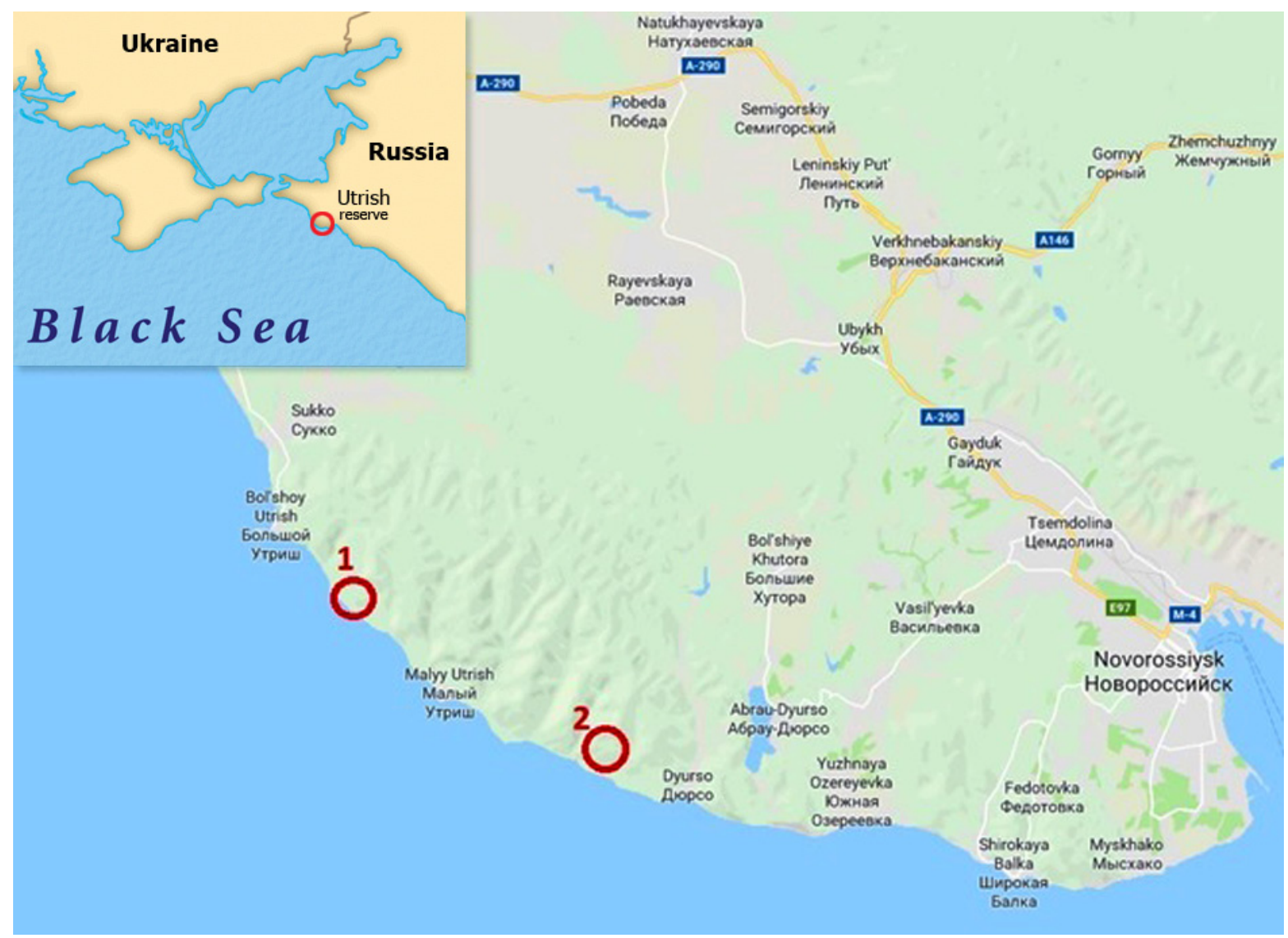

Fig. 1. Location of the study sites. Designations: 1) Vodopadnaya shchel'; 2) Sukhaya shchel'. 

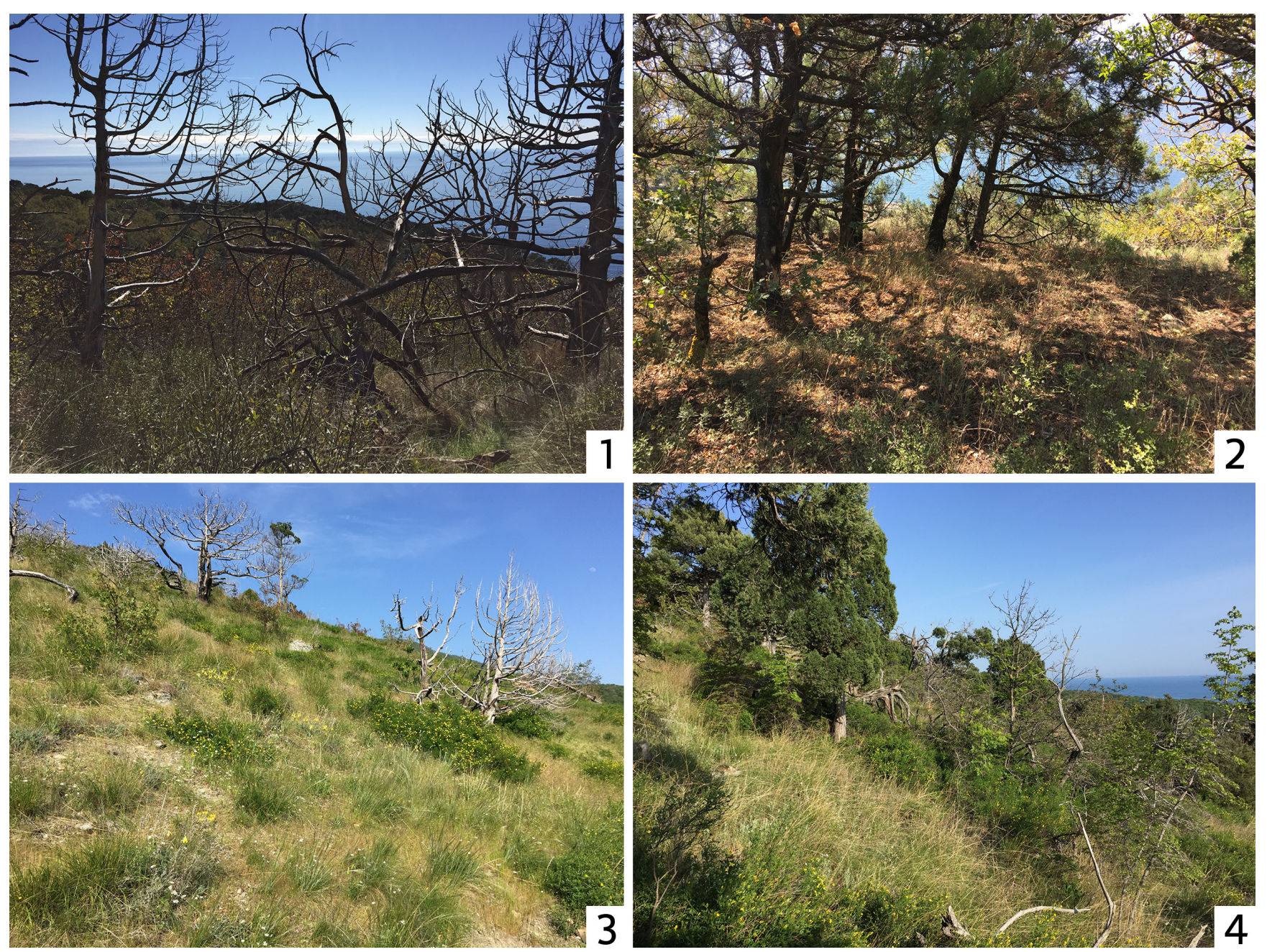

Fig. 2. View of study sites. Designations: 1-2 - Vodopadnaya shchel', 3-4 - Sukhaya shchel'; Left $(1,3)$ - post-fire sites; right $(2,4)$ - control sites.

Table 1. Characteristics of soil profiles

\begin{tabular}{|c|c|c|c|}
\hline № & Soil & Height in $\mathrm{m}$ a.s.l. & Geographical coordinates \\
\hline \multicolumn{4}{|c|}{ Post-fire site in the Vodopadnaya shchel', October 2016} \\
\hline U16 & Brown carbonate low stony post-fire soil & 120 & $44.9725 \mathrm{~N}, 37.579167 \mathrm{E}$ \\
\hline $\mathrm{U} 17$ & Brown carbonate low stony post-fire soil & 124 & $44.975556 \mathrm{~N}, 37.581389 \mathrm{E}$ \\
\hline U18 & Brown carbonate low stony eroded post-fire soil & 131 & $44.976667 \mathrm{~N}, 37.581667 \mathrm{E}$ \\
\hline \multicolumn{4}{|c|}{ Control site in the Vodopadnaya shchel', October 2016} \\
\hline U19 & Brown leached weakly stony underdeveloped soil & 139 & $44.980556 \mathrm{~N}, 37.5875 \mathrm{E}$ \\
\hline $\mathrm{U} 20$ & Brown carbonate stony soil & 110 & $44.970833 \mathrm{~N}, 37.569722 \mathrm{E}$ \\
\hline \multicolumn{4}{|c|}{ Post-fire site in the Vodopadnaya shchel', September 2018} \\
\hline Vs 1 & Brown carbonate stony post-fire soil & 117 & $44.9725 \mathrm{~N}, 37.579167 \mathrm{E}$ \\
\hline Vs 2 & Brown slightly leached stony post-fire soil & 115 & $44.971111 \mathrm{~N}, 37.577222 \mathrm{E}$ \\
\hline Vs 3 & Brown carbonate stony post-fire soil & 113 & $44.968611 \mathrm{~N}, 37.575278 \mathrm{E}$ \\
\hline \multicolumn{4}{|c|}{ Control site in the Vodopadnaya shchel', September 2018} \\
\hline Vs 4 & Brown leached stony soil & 113 & $44.969167 \mathrm{~N}, 37.571944 \mathrm{E}$ \\
\hline Vs 5 & Brown leached weakly stony soil & 106 & $44.970833 \mathrm{~N}, 37.565278$ \\
\hline Vs 6 & Brown humus weakly leached stony soil & 99 & $44.966389 \mathrm{~N}, 37.555556 \mathrm{E}$ \\
\hline \multicolumn{4}{|c|}{ Post-fire site in the Sukhaya shchel', April 2018} \\
\hline $\mathrm{S} 1 / 18$ & Brown leached highly stony post-fire soil & 57 & $44.751389 \mathrm{~N}, 37.650833 \mathrm{E}$ \\
\hline \multicolumn{4}{|c|}{ Control site in the Sukhaya shchel', April 2018} \\
\hline $\mathrm{S} 2 / 18$ & Brown leached stony soil & 60 & $44.751111 \mathrm{~N}, 37.678611 \mathrm{E}$ \\
\hline
\end{tabular}


Geographical co-ordinates were obtained using a GPS Garmin navigator. The temperature was determined with a HANNA CHECTEMP electronic thermometer. The moisture content (volumetric) of the soil was determined in the field using a Fieldscout TDR 100 moisture meter from Spectrum Technologies Inc. (USA) in 10-fold repetition on each study site.

Analytical studies were performed at the Department of Ecology and Environmental Management of the Southern Federal University (Rostovon-Don, Russia) using methods accepted in ecology, biology and soil science (Kazeev et al., 2016).

The content of organic carbon in humus was determined using the method of oxidation with a chromic mixture on a spectrophotometer UNICO 1201 (United Products \& Instruments, Inc., USA). The reaction of the soil environment $(\mathrm{pH})$ and the redox potential was determined by a potentiometric method (HANNA HI 98128 pHep 5, Germany) in soil suspension with a soil : water ratio of $1: 2.5$ ( $10 \mathrm{~g}$ soil to $25 \mathrm{ml}$ water). The content of easily soluble salts was determined by conductometry on the basis of electrical conductivity (EC) by HANNA HI 9034, Germany. The carbonate content is determined by the volumetric method with the addition of $\mathrm{HCl}$ solution (AFNOR X 31-105). The total number of bacteria was determined by the method of luminescent microscopy with sample staining with acridine orange (Merck KGaA, Germany). It should be noted that staining with appropriate dyes allows only the total number of bacteria and fungi in the soil sample to be determined, but not the physiological status of the cells. The green cells of bacteria were counted with a ZEISS inverted microscope, AXIO Vert. A1 model with a 450-490 nm filter (CARL ZEISS, Germany). The intensity of carbon dioxide release - soil respiration was determined according to Galstyan (1978) using carbon dioxide as an absorber sodium hydroxide solution. For this purpose, $10 \mathrm{~g}$ of moist soil for $24 \mathrm{~h}$ was placed in a flask with $0.1 \mathrm{~mol} / \mathrm{dm}^{3}$ $\mathrm{NaOH}$ solution, which was then titrated with 0.05 $\mathrm{mol} / \mathrm{dm}^{3}$ hydrochloric acid solution.

The enzymatic soil activity was estimated on the basis of the activity of different enzyme classes: oxidoreductases (catalase, dehydrogenase) and hydrolases ( $\beta$-fructofuranosidase (invertase), phosphatase, and urease). Determination of the enzymatic soil activity was based on the amount of the substrate processed during the reaction or the formation of the reaction product under optimal conditions of temperature, $\mathrm{pH}$ of the medium, concentration of the substrate and soil hinge. The catalase activity $\left(\mathrm{H}_{2} \mathrm{O}_{2}: \mathrm{H}_{2} \mathrm{O}_{2}\right.$-oxidoreductase, EC 1.11.1.6.) was determined by the volumetric method according to the volume of decomposed hydrogen peroxide per 1 min (Galstyan, 1978). The activity of dehydrogenases (substrate: NAD(F)oxidoreductase, EC 1.1.1) was determined using triphenyltetrazolium reduced to triphenylformazane (Galstyan, 1978). The peroxidase activity (donor: $\mathrm{H}_{2} \mathrm{O}_{2}$-oxidoreductase, $\mathrm{EC}$ 1.11.1.7.) was determined using hydroquinone reduced to 1,4-pbenzoquinone. The urease activity (carbamideamidohydrolase, EC 3.5.1.5.) was determined by the amount of ammonia formed during the urea hydrolysis. The phosphatase activity (phosphohydrolases of monoethers of orthophosphoric acid (EC 3.1.3.1-2) was determined using phenolphthalein sodium phosphate solution as a substrate (Khaziev, 2005). According Galstyan (1978), the activity of soil enzymes was studied at the natural soil $\mathrm{pH}$ without buffer, in 3-6-fold repetition. The control for determining the activity of enzymes was carried out by the use of substrates without soil. The method of determining the biological activity of soils by fluorescein diacetate (FDA) hydrolysis was based on the ability of enzyme complexes produced by soil microflora to hydrolyse a colourless FDA reagent to form brightly coloured fluorescein (Adam \& Duncan, 2001). The FDA hydrolysis was carried out by various enzymes, such as proteases, lipases and esterases.

To combine several parameters, a methodology was used to determine the integral parameter of the biological state (IPBS) of the soil (Kazeev et al., 2003). This method allowed evaluating the set of biological parameters. For this, the value of each parameter in the control soil was taken as $100 \%$. In the post-fire soil, this parameter value was expressed as a percentage in relation to it as follows:

$$
\mathrm{B} 1=\frac{\mathrm{Bx}}{\mathrm{Bc}} \times 100 \%,
$$

where $\mathrm{B} 1$ is the relative score of the parameter, $\mathrm{Bx}$ is the actual value of the parameter in the postfire soil, $\mathrm{Bc}$ is the value of the parameter in the control soil.

After that, the average estimated score of the studied parameters for the sample was calculated. The absolute values cannot be summed, since they have different units of measurement (mg, $\%$, etc.). The integral parameter of the biological status of the soil was calculated according to the following formula: 


$$
\mathrm{IPBS}=\frac{\mathrm{Ba}}{\mathrm{Ba} \cdot \mathrm{c}} \times 100 \%,
$$

where $\mathrm{Ba}$ - average estimated score of all parameters in post-fire soil, Ba.c - estimated score of all parameters under control.

The biological properties of the soil are characterised by a high degree of variation. Therefore, in order to obtain reliable data, thorough statistical processing is required. We determined the parameters of variation and carried out a correlation analysis (Jongman et al., 1995). Statistical processing of the obtained results was carried out using Statistica 10.0 and Excel. We used the arithmetic average value $(\mathrm{M})$, and standard error of the mean (m). A correlation analysis was used to study the closeness and shape of the relationship between various parameters of the ecological and biological status of the soil.

\section{Results and Discussion}

The investigation on the study site in the Vodopadnaya shchel' has been conducted in 2016 and 2018. In 2016, burnt sites with different soil cover were studied. The soils differed in thickness, stoniness degree, washing away and leaching from carbonates. Seven years after the wildfire impact, the vegetation cover on study site 1 was significantly altered; old trees had died and charred; the projective cover of the grasses and shrubs varied widely, and there were areas with a bare, strongly stone-like surface. The genetic profile of the brown soils of the study area had some differences from the soils described in Valkov et al. (2008). The differences can be explained by the low mountainous dissected relief of the study site and the soil gritty. First of all, it was a shorter soil profile; its high stoniness and rubble; the absence of carbonate neoplasms; in some cases, the presence of fragmentary low-power forest litter.

In the autumn of 2016, at different locations, the soil temperature changed significantly, depending on the vegetation cover. The soils of the shaded forest areas (U19, U20) were significantly cooler $\left(\mathrm{T}=14.4^{\circ} \mathrm{C}, \mathrm{p}<0.05\right)$ than the burnt areas occupied by grass and shrub vegetation (U16, $\left.\mathrm{U} 17, \mathrm{~T}=17.9^{\circ} \mathrm{C}\right)$ or a practically bare area (U18, $\mathrm{T}=24.8^{\circ} \mathrm{C}$ ). Differences in temperature persisted across the soil profile. The humidity of the surface horizons of all soils was low (10-12\%). The average variation level did not remarkably differ in different areas. The reaction of the medium and the electrical conductivity of the soil (EC) were almost at the same level, regardless of the area under study. A significant change in the values in the soils of different areas has been established only for the content of carbonates. According to this parameter, we distinguished carbonate and leached soil variants. The content of calcium carbonates in soils is ambiguous for the biota and biological activity of the soils in the Western Caucasus. It determines the response of the environment, acidity and soil saturation with bases (Kazeev et al., 2012). The brown soils and rendzins leached from carbonates have a reduced medium response, higher density, and lower water resistance of the aggregates. Under the subtropical conditions on the Black Sea coast of the Caucasus, the carbonate content in soils does not have such a decisive value on the degree of their biogenicity and biological activity in comparison to the more humid conditions of the Caucasus. However, on the study site, the differences in carbonate content were not directly related to the fire-induced effect. The variation in carbonate content was associated with local limestone outcrops close to the soil surface. Layers of limestone alternate with carbonate-free rocks (sandstones and mudstones). All these rocks regularly alternate in flysch with the layered nature of dense rock layers with different carbonate content. Flysch is a series of marine sedimentary rocks that are mainly of detrital origin and characterised by the alternation of several lithological layers (Vassoevich, 1948). Flysch formations are formed at the bottom of the sea. The cycles are from a few centimeters to several decimeters thick and consist of 2-4 layers. The lower layers sometimes contain a conglomerate or breccia, turning into sandstone, aleurolite, detrital limestone, and the upper layers are composed of pelites.

As a result of our study, we found a significant impact of wildfire effects on the ecological and biological soil properties in the Vodopadnaya shchel' of the Utrish State Nature Reserve. Even seven years after the wildfire in the juniper woodland, many biological properties had changed significantly compared with the control sites. According Gongalsky (2011), 2-7 years after the wildfire influence in the forest on brown soils in the vicinity of Malyi Utrish, the abundance and diversity of the soil mesofauna was lower than in the control forest site. The mesofauna abundance was determined by the time of the post-fire period. Seven years after the wildfire impact, the mesofauna abundance was two times higher in comparison to a two-year fire. However, in the control 
forest the number was still higher (more than two times). On the cinders, soil animals were confined to spots of unburnt litter.

As a result of the 2016 study, we noted differences in the organic matter content in the soils of the studied sites, seven years after the wildfire (Table 2, Fig. 3). The carbon content of humus in the surface horizons of the studied soil variants was high (6.4-8.0\%). The exception was formed by the soils of the strongly changed section U18, where the humus content had decreased to an average level $(4.3 \%)$, because of erosion processes. In the surface horizons of the burnt soil, the humus content had reduced by more than $20 \%$ in relation to the soils in the control areas. The post-fire organic matter reduction has been associated with more intense burning of organic material (litter, rags, stubble) on the soil surface with a high degree of the fire-induced effect (Valkov et al., 1996; Odabashyan et al., 2017; Lucas-Borja et al., 2018; Adkins et al., 2019). In the studied soils, the total number of bacteria varied in a wide range - from 2.2 billion $\times \mathrm{g}^{-1}$ to 25 billion $\times \mathrm{g}^{-1}$ in soil (Table 2 ).

In post-fire soils, the number of bacteria varies in a very wide range $\left(2.2-25.0\right.$ billion $\left.\times \mathrm{g}^{-1}\right)$ depending on the development of the post-fire succession. An increased number of bacteria has been noted on the turfed areas. At the same time, a high variation of biological parameters has been noted in profiles and pits. The variation is associated both with the peculiarities of the mountain relief, and the nature of the vegetation, which forms refugia different in the number of plant residues. One of these variable parameters was the intensity of carbon dioxide production by soils. This important parameter is an integral parameter of soil biological activity. In the surface soil horizons of the post-fire area, the respiration intensity values $\left(14.1 \pm 2.5 \mathrm{mg} \mathrm{CO} \times 100 \mathrm{~g}^{-1} \times 24 \mathrm{~h}^{-1}\right)$ were, on average, $40 \%$ lower $(\mathrm{p}<0.05)$ than the control values $\left(23 \pm 3.3 \mathrm{mg} \mathrm{CO} \times 100 \mathrm{~g}^{-1} \times 24\right.$ $\left.\mathrm{h}^{-1}\right)$. In post-fire soils, the suppression of carbon dioxide emissions was also noted by other authors (Lucas-Borja et al., 2018; Adkins et al., 2019).

In 2016, the enzymatic activity in the studied post-fire soils was reduced by $14-24 \%$. The highest activity inhibition was found for invertase, which is closely related to the organic matter of the soil. The wildfire inhibited the soil oxidoreductase activity to a lesser extent. Other authors also noted the decrease in the activity of enzymes ( $\beta$-glucosidase, urease, and phosphatase) in proportion to the degree of fire-induced effects in the soils of forest ecosystems in different regions of Spain (Lucas-Borja et al., 2018; Fernández-García et al., 2019). An exception to the general pattern was the total number of bacteria. Its values increased on average by $15 \%$ in post-fire soils. This resulted in an increase in temperature of the post-fire soils, which limits the biological processes in the soils in autumn. The IPBS of postfire soils, calculated by using values of carbon dioxide emission intensity, enzyme activity, humus content and the number of bacteria, has been reduced by $17 \%$ in relation to the values in soils of the control areas.

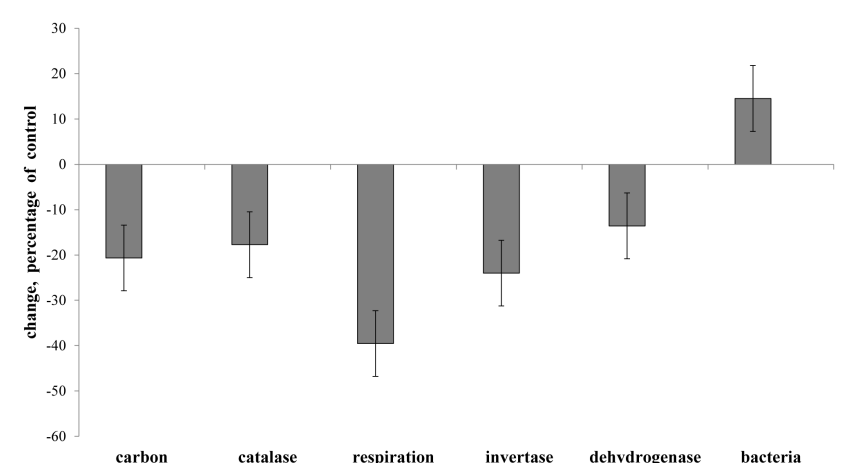

Fig. 3. Post-fire changes in the biological activity of the upper soil layer $(0-10 \mathrm{~cm})$ in the Vodopadnaya shchel', October 2016.

Table 2. The organic carbon content and the number of bacteria in soils of the Vodopadnaya shchel', October 2016

\begin{tabular}{|c|c|c|c|c|c|c|}
\hline \multirow{2}{*}{ № } & \multirow{2}{*}{ Soil } & \multirow{2}{*}{$\begin{array}{l}\text { Depth } \\
\text { in } \mathrm{cm}\end{array}$} & \multicolumn{2}{|c|}{ Organic carbon, $\%$} & \multicolumn{2}{|c|}{ number of bacteria, billion $\times \mathrm{g}^{-1}$} \\
\hline & & & $\mathrm{M}$ & $\mathrm{m}$ & $\mathrm{M}$ & $\mathrm{m}$ \\
\hline \multirow{2}{*}{ U16 } & \multirow{2}{*}{ Brown carbonate low stony post-fire soil } & $0-10$ & 6.4 & 1.48 & 7.5 & 4.8 \\
\hline & & $15-25$ & 5.8 & 0.06 & 6.8 & 0.09 \\
\hline \multirow{3}{*}{ U17 } & \multirow{3}{*}{ Brown carbonate low stony post-fire soil } & $0-10$ & 7.5 & 1.63 & 25.0 & 3.30 \\
\hline & & $12-22$ & 7.0 & 0.04 & 6.3 & 0.52 \\
\hline & & $25-35$ & 3.0 & 0.01 & 4.2 & 0.37 \\
\hline \multirow{2}{*}{ U18 } & \multirow{2}{*}{ Brown carbonate low stony eroded post-fire soil } & $0-10$ & 4.3 & 1.62 & 2.2 & 0.39 \\
\hline & & $15-25$ & 3.6 & 0.11 & 4.2 & 0.43 \\
\hline \multirow{2}{*}{ U19 } & \multirow{2}{*}{ Brown leached low stony underdeveloped soil } & $0-10$ & 8.0 & 1.77 & 4.1 & 1.47 \\
\hline & & $10-20$ & 2.9 & 0.02 & 5.3 & 0.04 \\
\hline \multirow{3}{*}{$\mathrm{U} 20$} & \multirow{3}{*}{ Brown carbonate stony soil } & $0-10$ & 7.3 & 1.53 & 4.3 & 0.51 \\
\hline & & $12-22$ & 4.2 & 0.19 & 3.9 & 0.54 \\
\hline & & $23-32$ & 2.7 & 0.09 & 3.8 & 0.21 \\
\hline
\end{tabular}

Note: $\mathrm{M}$ - arithmetic average value; $\mathrm{m}$ - standard error of the mean. 
The correlation data analysis (Table 3 ) showed a relationship between the humus content and catalase activity $(\mathrm{R}=0.63)$ and the soil respiration intensity $(\mathrm{R}=0.57)$. The activity of dehydrogenases correlated with the invertase activity $(R=0.98)$, respiration intensity $(\mathrm{R}=0.64)$ and carbonate content $(\mathrm{R}=0.58)$. The invertase activity associated also with the carbonate content $(\mathrm{R}=0.70)$. We did not find such relationship for the catalase activity $(\mathrm{R}=-0.30)$. However, an increase in the activity of this enzyme in carbonate soils was noted previously as compared to carbonate-free soils (Kazeev et al., 2004; Dadenko et al., 2009, 2014).

In the subsurface soil layer $(10-25 \mathrm{~cm})$ in the Abraus peninsula, the fire-induced effects did not determine differences in biological properties. However, the wildfire affects indirectly these parameters through the subsequent change in vegetation and hydrothermal conditions. In the mineral soil horizons, the carbon content is not changed depending on the fire degree (Adkins et al., 2019). The wildfire had little impact on the biological properties of soils under the forest conditions in the mineral layer of $0-5 \mathrm{~cm}$ in brown soil in Italy (Catalanotti et al., 2018) and Spain (Girona-García et al., 2018). The differences between the values of the investigated parameters were very significant. Also, these varied highly depending on the location of the study site (Fig. 4). In this layer, only the activity of dehydrogenases demonstrated low values. Catalase activity was almost at the level of control values. In this layer and in the surface layer the number of bacteria increased by $26 \%$ after the fire influence. In the layer of $10-25 \mathrm{~cm}$ of post-fire soils, the humus content and invertase activity increased respectively by $53 \%$ and $38 \%$ compared with the control values in contrast to the surface horizons of this soil.
As reflected in the IPBS, the total changes in biological activity increased by $18 \%$ in this layer of post-fire soils. All these changes were associated with changes in the vegetation character in the fire-damaged areas. A change in the composition of the ground cover led to a change in the nature of humus accumulation and the biological soil activity. Restorative succession has led to a change in grass vegetation. At the same time, the nature of the input of organic substances into the soil has changed. A woody vegetation contributed to the preferential transition of plant residues to the soil surface with the formation of a local thin litter. The lower soil layers in the control areas are characterised by a sharp decrease in the content of organic residues, plant roots and humus. The turf process, caused by an increase in the proportion of grasses, led to the enrichment of subsurface soil horizons in the burnt areas. Accordingly, in the 10-25 cm layer of post-fire soils, the humus content is lower than that in the $0-10 \mathrm{~cm}$ surface layer by only $9 \%$. At the same time, in the xerophytic control forest, the decrease in the humus content was $53 \%$ due to its transition to the lower layer.

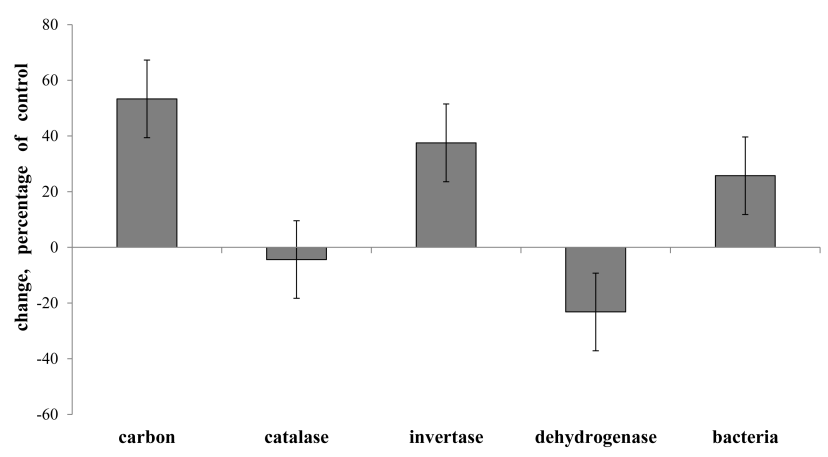

Fig. 4. Post-fire changes in the biological activity of the 10 $25 \mathrm{~cm}$ soil layer in the Vodopadnaya shchel', October 2016.

Table 3. Correlation matrix of indicators in the surface soil layer $(0-10 \mathrm{~cm})$ in the Vodopadnaya shchel', October 2016

\begin{tabular}{|c|c|c|c|c|c|c|c|c|c|}
\hline Parameters & $\frac{\pi}{2}$ & $\bigcup_{I I}^{U}$ & 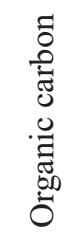 & 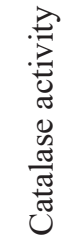 & 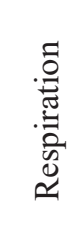 & 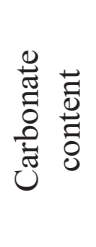 & 总 & 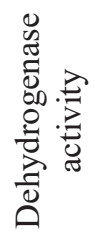 & 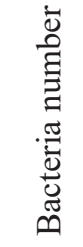 \\
\hline $\mathrm{pH}$ & 1.00 & 0.05 & 0.53 & 0.35 & -0.31 & 0.40 & 0.23 & 0.13 & -0.28 \\
\hline $\mathrm{EC}$ & & 1.00 & 0.48 & 0.94 & 0.58 & -0.35 & 0.30 & 0.31 & -0.43 \\
\hline Organic carbon & & & 1.00 & 0.63 & 0.57 & -0.15 & 0.32 & 0.40 & 0.39 \\
\hline Catalase activity & & & & 1.00 & 0.41 & -0.30 & 0.24 & 0.23 & -0.42 \\
\hline Respiration & & & & & 1.00 & -0.24 & 0.48 & 0.64 & 0.57 \\
\hline Carbonate content & & & & & & 1.00 & 0.70 & 0.58 & -0.03 \\
\hline Invertase activity & & & & & & & 1.00 & 0.98 & 0.08 \\
\hline Dehydrogenase activity & & & & & & & & 1.00 & 0.26 \\
\hline Bacteria number & & & & & & & & & 1.00 \\
\hline
\end{tabular}


Re-investigations conducted in this area after two years (in 2018) showed a high variation in the values of biological parameters in the Vodopadnaya shchel'. This applies also to the post-fire area and the control forest area. The reasons for the high variation were mentioned above. However, almost no differences were found between the post-fire and the control areas regarding soil environment reaction, and carbonate content. It also indicates the discrepancy between the values of biological parameters in post-fire and control soils (Fig. 5). We identified a change in the nature of trend parameters in contrast to the results of the 2016 studies. The dynamics of different parameters of the biological status of the soil differed. In post-fire soils, we noted a significant decrease only for the humus content and peroxidase activity. In the post-fire soil, the catalase activity was almost indistinguishable from control. At the same time, the activity of soil hydrolases (invertase and urease) increased by $19-25 \%$ in post-fire soils.

In April 2018, we performed investigations on study site 2 near the Sukhaya shchel'. At this location, the brown soil had a high humus content in the upper horizon (6.5\%) in the control area. The humus content in the $\mathrm{AB}$ horizon $(15-25 \mathrm{~cm})$ was $3.8 \%$. Five years after the fire impact, the post-fire soil contained almost half of the humus amount in the 5 $\mathrm{cm}$ surface layer compared to the soil in the control area of juniper (Pistacia atlantica, Juniperus excelsa, J. foetidissima, J. oxycedrus) woodland (Fig. 6).

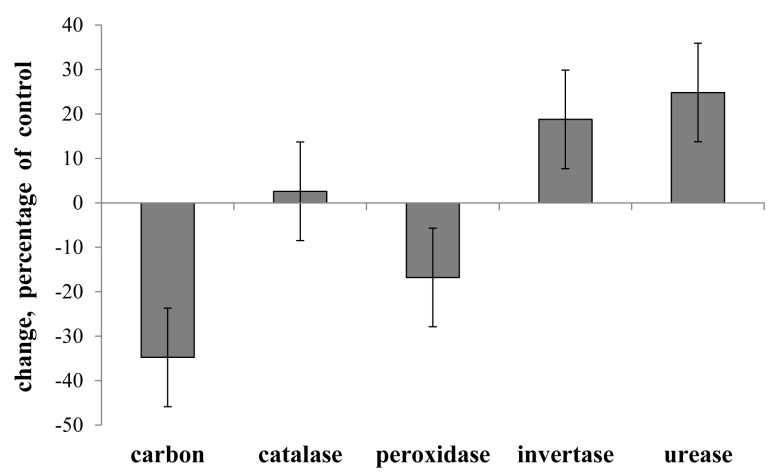

Fig. 5. Post-fire changes in the biological activity of the upper soil layer $(0-10 \mathrm{~cm})$ in the Vodopadnaya shchel', September 2018.

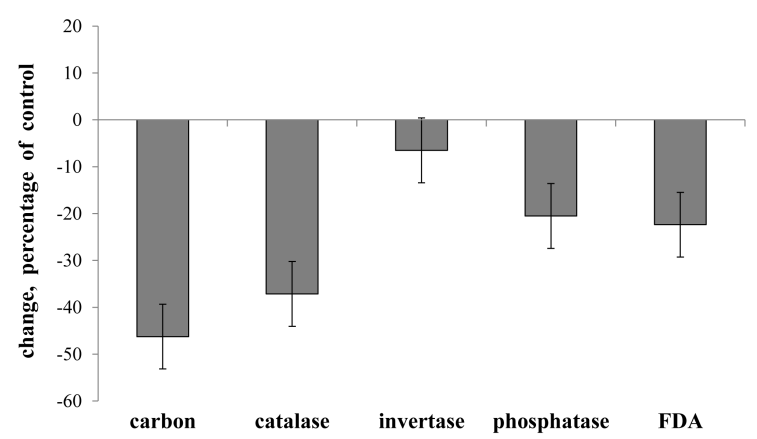

Fig. 6. Post-fire changes in the biological activity of the upper soil layer $(0-10 \mathrm{~cm})$ in the Sukhaya shchel', April 2018.
The post-fire changes affected not only the surface soil layer, but also the underlying soil horizons. At a depth of 15-25 cm, the differences between the soil areas remain at the same level as for the upper soil horizons. At the same time, it was noted previously that in different soils, the fire-induced effect directly affects only the surface soil horizons, and the changes do not concern the soil profile (Odabashyan et al., 2017; Adkins et al., 2019). It should be noted that the studied soils also differed in the stony profile degree. In the control area, the stony profile was $50 \%$ in the middle part of the profile. In the burnt area, the amount of rubble raised to $80 \%$. This fact further increased the differences in the humus status of the brown soils. Among soil enzymes, the highest decrease was found for the catalase activity. The hydrolase activity has been reduced to a lesser extent. Our studies have shown a significant dependence of the brown soil properties on the time of observation in the Utrish State Nature Reserve. Some indicators ( $\mathrm{pH}$, electrical conductivity, carbonate content, invertase activity) changed to a higher extent than in areas with different fire effects. This fact is consistent with studies of soils in the European Mediterranean area (Catalanotti et al., 2018). The authors have demonstrated that fire-induced changes in organic carbon and microbial activity were generally less than fluctuations over a time.

\section{Conclusions}

On the Abraus peninsula, post-fire recovery succession developed during 5-9 years after the fire impact in the grass-shrub stage. Fires have a significant impact on the biological properties (organic carbon content, bacteria number, soil respiration, activity of extracellular enzymes) in the brown soils of the Abraus peninsula. As a rule, the biological properties of post-fire soils in the Utrish State Nature Reserve are significantly inferior to the control values of soils that are not fire-affected. The wildfire had the highest impact on the surface soil horizons $(0-10 \mathrm{~cm})$. The soil respiration intensity was $40 \%$ in fire-damaged areas. In burnt areas, the organic carbon content was 20-45\% lower than in the soils in control forest areas. In fire-damaged soils, the activity of oxidoreductases (catalase, peroxidase, dehydrogenase) has reduced by $14-37 \%$. And the activity of hydrolases (invertase, urease, phosphatase) varied irregularly at different sites. The degree of differences in biological parameters depends on the age of the post-fire area. If less time has passed since the fire impact, the differences 
identified for the brown soils were higher. Even nine years after the fire, many parameters differed significantly in comparison to the control areas in juniper (Pistacia atlantica, Juniperus excelsa, J. foetidissima, J. oxycedrus) woodland.

\section{Acknowledgements}

Financial support for the study was provided by the Utrish State Nature Reserve (contract №68-2018 dated 06/20/2018). The study was conducted within the framework of the Ministry of Education and Science of the Russian Federation (5.5735.2017/8.9) and by the state support of the leading scientific school of the Russian Federation (HШ-3464.2018.11).

\section{References}

Adam G., Duncan H. 2001. Development of a sensitive and rapid method for the measurement of total microbial activity using fluorescein diacetate (FDA) in a range of soils. Soil Biology and Biochemistry 33(7-8): 943-951. DOI: 10.1016/S00380717(00)00244-3

Adkins J., Sanderman J., Miesel J. 2019. Soil carbon pools and fluxes vary across a burn severity gradient three years after wildfire in Sierra Nevada mixed-conifer forest. Geoderma 333: 10-22. DOI: 10.1016/j.geoderma.2018.07.009

Alcañiz M., Outeiro L., Francos M., Farguell J., Úbeda X. 2016. Long-term dynamics of soil chemical properties after a prescribed fire in a Mediterranean forest (Montgrí Massif, Catalonia, Spain). Science of the Total Environment 572: 1329-1335. DOI: 10.1016/j.scitotenv.2016.01.115

Bünemann G.E.K., Bongiorno G., Bai Z., Creamer R.E., De Deyn G., de Goede R., Fleskens L., Geissen V., Kuyper T.W., Mäder P., Pulleman M., Sukkel W., van Groenigen J.W., Brussaard L. 2018. Soil quality - A critical review. Soil Biology and Biochemistry 120: 105-125. DOI: 10.1016/j.soilbio.2018.01.030

Burns R.G., DeForest J.L., Jürgen M., Sinsabaugh R.L., Stromberger M.E., Wallenstein M.D., Weintraub M.N., Zoppini A. 2013. Soil enzymes in a changing environment: Current knowledge and future directions. Soil Biology and Biochemistry 58: 216-234. DOI: $10.1016 /$ j.soilbio.2012.11.009

Catalanotti A.E., Giuditta E., Marzaioli R., Ascoli D., Esposito A., Strumia S., Mazzoleni S., Rutigliano F.A. 2018. Effects of single and repeated prescribed burns on soil organic $\mathrm{C}$ and microbial activity in a Pinus halepensis plantation of Southern Italy. $A p-$ plied Soil Ecology 125: 108-116. DOI: 10.1016/j. apsoil.2017.12.015

Dadenko E.V., Kazeev K.S., Kolesnikov S.I., Valkov V.F. 2009. Changes in the enzymatic activity of soil samples upon their storage. Eurasian Soil Science 42(12): 1380-1385.
Dadenko E.V., Myasnikova M.A., Kazeev K.Sh., Kolesnikov S.I., Valkov V.F. 2014. Biological activity of ordinary chernozem with long-term use under arable land. Eurasian Soil Science 6: 724-733. [In Russian]

Demina O.N., Rogal L.L., Suslova E.G., Dmitriev P.A., Kozhin M.N., Seregin A.P., Bykhalova O.N. 2015. Synopsis of the flora of the State Natural Reserve «Utrish». Zhivye i biokosnye sistemy 13. Available from http://www.jbks.ru/archive/issue-13/article-8 [In Russian]

Dose H.L., Fortuna A.M., Cihacek L.J., Norland J., DeSutter T.M., Clay D.E., Bell J. 2015. Biological indicators provide short term soil health assessment during sodic soil reclamation. Ecological Indicators 58: 244-253. DOI: 10.1016/j.ecolind.2015.05.059

Fernández-García V., Miesel J., Baeza M.J., Marcos E., Calvo L. 2019. Wildfire effects on soil properties in fire-prone pine ecosystems: Indicators of burn severity legacy over the medium term after fire. Applied Soil Ecology 135: 147-156. DOI: 10.1016/j.apsoil.2018.12.002

Fonseca F., Figueiredo T., Nogueira C., Queirós A. 2017. Effect of prescribed fire on soil properties and soil erosion in a Mediterranean mountain area. Geoderma 307: 172-180. DOI: 10.1016/j.geoderma.2017.06.018

Francos M., Úbeda X., Pereira P., Alcañiz M. 2018. Long-term impact of wildfire on soils exposed to different fire severities. A case study in Cadiretes Massif (NE Iberian Peninsula). Science of the Total Environment 615: 664-671. DOI: 10.1016/j.scitotenv.2017.09.311

Galstyan A.Sh. 1978. Unification of methods for studying the activity of soil enzymes. Eurasian Soil Science 2: 107-114. [In Russian]

Girona-García A., Badía-Villas D., Martí-Dalmau C., Ortiz-Perpíña O., Mora J.L., Armas-Herrera C.M. 2018. Effects of prescribed fire for pasture management on soil organic matter and biological properties: A 1-year study case in the Central Pyrenees. Science of the Total Environment 618: 1079-1087. DOI: $10.1016 /$ j.scitotenv.2017.09.127

Gongalsky K.B. 2011. The spatial distribution of large soil invertebrates on burned areas in xerophilous ecosystems of the Black sea coast of the Caucasus. Arid Ecosystems 1(4): 260-266. DOI: 10.1134/ S2079096111040068

Hobley E.U., Le Gay Brereton A.J., Wilson B. 2017. Forest burning affects quality and quantity of soil organic matter. Science of the Total Environment 575: 41-49. DOI: 10.1016/j.scitotenv.2016.09.231

Hugh H.A.L. 2012. Soil extracellular enzyme dynamics in a changing climate. Soil Biology and Biochemistry 47: 53-59. DOI: 10.1016/j.soilbio.2011.12.026 Jongman R.G.G., Ter Braak S.J.F., Van Torgeren O.F.R. 1995. Data Analysis in Community and Landscape Ecology. Cambridge: Cambridge University Press. 324 p. 
Kazeev K.S., Kutrovskii M.A., Dadenko E.V., Vezdeneeva L.S., Kolesnikov S.I., Valkov V.F. 2012. The influence of carbonates in parent rocks on the biological properties of mountain soils of the northwest Caucasus region. Eurasian Soil Science 45(3): 282289. DOI: 10.1134/S1064229312030052

Kazeev K.Sh., Kolesnikov S.I., Akimenko Yu.V., Dadenko E.V. 2016. Methods of bio-diagnostics of terrestrial ecosystems. Rostov-on-Don: Southern Federal University. 356 p. [In Russian]

Kazeev K.Sh., Kolesnikov S.I., Bykhalova O.N. 2013. Brown soils of the Utrish Reserve. In: Biodiversity of the Utrish State Nature Reserve. Vol. 1. Anapa. P. 154-163. [In Russian]

Kazeev K.Sh., Kolesnikov S.I., Valkov V.F. 2003. Biological diagnostics and indication of soils: methodology and research methods. Rostov-on-Don: Rostov State University. 204 p. [In Russian]

Kazeev K.Sh., Kolesnikov S.I., Valkov V.F. 2004. Soil biology of the South of Russia. Rostov-on-Don: Publisher of CVVR. 350 p. [In Russian]

Khanina L.G., Smirnov V.E., Romanov M.S., Bobrovsky M.V. 2018. Effect of spring grass fires on vegetation patterns and soil quality in abandoned agricultural lands at local and landscape scales in Central European Russia. Ecological Processes 7: 38. DOI: 10.1186/s13717-018-0150-8

Khaziev F.Kh. 2005. Methods of soil enzymology. Moscow: Nauka. 252 p. [In Russian]

Kuleshova L.V., Korotkov V.N., Potapova N.A., Evstigneev O.I., Kozlenko A.B., Rusanova O.M. 1996. Complex analysis of post-fire successions in the forests of the Kostomuksha State Nature Reserve (Karelia). Bulletin of Moscow Society of Naturalists 101(4): 3-15. [In Russian]

Kutrovsky M.A., Valkov V.F., Kazeev K.Sh., Kolesnikov S.I. 2008. Ecological features of rendzin of the Black Sea coast of the Caucasus. University news. North-Caucasian region. Natural sciences series 6: 97-101. [In Russian]

Lucas-Borja M.E., Calsamiglia A., Fortesa J., GarcíaComendador J., Guardiola E.L., García-Orenes F., Gago J., Estrany J. 2018. The role of wild fire on soil quality in abandoned terraces of three Mediterranean micro-catchments. Catena 170: 246-256. DOI: 10.1016/j.catena.2018.06.014

Magzanova D.K., Khiyalieva R.G. 2013. Investigation of the influence of field fires on the state of soil micro- biocenosis. Advances in Modern Natural Science 4: 160-161. [In Russian]

Maksimova E.Y., Abakumov E.V., Kudinova A.G. 2017. Functional activity of soil microbial communities in post-fire pine stands of Tolyatti, Samara oblast. Eurasian Soil Science 50(2): 239-245. DOI: 10.1134/ S1064229317020119

Moya D., González-De Vega, Lozano E., García-Orenes F., Mataix-Solera J., Lucas-Borja M.E., de Las Heras J. 2019. The burn severity and plant recovery relationship affect the biological and chemical soil properties of Pinus halepensis Mill. stands in the short and midterms after wildfire. Journal of Environmental Management 235: 250-256. DOI: 10.1016/j.jenvman.2019.01.029

Odabashyan M.Yu., Trushkov A.V., Kazeev K.Sh., Kolesnikov S.I. 2017. The influence of the fall on the enzymatic activity of chernozem. Proceedings of Samara Scientific Centre of RAS 19(2-3): 482-485. [In Russian]

Pingree M.R.A., DeLuca T.H. 2018. The influence of fire history on soil nutrients and vegetation cover in mixed-severity fire regime forests of the eastern Olympic Peninsula, Washington, USA. Forest Ecology and Management 422: 95-107. DOI: 10.1016/j. foreco.2018.03.037

Raiesi F., Salek-Gilani S. 2018. The potential activity of soil extracellular enzymes as an indicator for ecological restoration of rangeland soils after agricultural abandonment. Applied Soil Ecology 126: 140147. DOI: 10.1016/j.apsoil.2018.02.022

Valkov V.F., Kazadaev A.A., Kremenitsa A.M., Suprun V.A., Sukhanova V.M., Tashchiev S.S. 1996. The effect of stubble burning on chernozem biota. Eurasian Soil Science 29(12): 1412-1416. [In Russian]

Valkov V.F., Kazeev K.Sh., Kolesnikov S.I. Kutrovsky M.A. 2007. Soil formation on limestone and marl. Rostov-on-Don: Rostizdat. 198 p. [In Russian]

Valkov V.F., Kazeev K.Sh., Kolesnikov S.I. 2008. Soils of the South of Russia. Rostov-on-Don: Everest Publishing House. 276 p. [In Russian]

Vassoevich N.B. 1948. Flysch and methods of its study. Leningrad; Moscow: Gostoptekhizdat. 216 p. [In Russian]

Wardle D.A., Nilsson M.C., Zackrisson O. 2008. Firederived charcoal causes loss of forest humus. Science 320(5876): 629-630. DOI: 10.1126/science. 1154960 


\title{
ПОСТПИРОГЕННОЕ ИЗМЕНЕНИЕ БИОЛОГИЧЕСКИХ СВОЙСТВ КОРИЧНЕВЫХ ПОЧВ ЗАПОВЕДНИКА «УТРИШ» (РОССИЯ)
}

\author{
К. Ш. Казеев ${ }^{1, *}$, Т. А. Полторацкая ${ }^{1}$, А. С. Якимова ${ }^{1}$, \\ М. Ю. Одабашян ${ }^{1}$, А. К. Шхапацев ${ }^{2}$, С. И. Колесников ${ }^{1}$ \\ ${ }^{1}$ Южный федеральный университет, Россия \\ *e-mail:kamil_kazeev@mail.ru \\ ${ }^{2}$ Майкопский государственный технологический университет, Россия \\ e-mail:6620607-11@mail.ru
}

Уникальные экосистемы Абраусского полуострова Черноморского побережья Кавказа, сохранившиеся в заповеднике «Утриш» представлены сухими восточно-средиземноморскими субтропиками с большим числом эндемиков и реликтов, сохранившимся с третичного периода. Это одно из немногих в России мест произрастания можжевелово-фисташковых (Pistacia atlantica, Juniperus excelsa, J. foetidissima, J. oxycedrus) редколесий. В 2016-2018 гг. проведено исследование содержания биологических свойств коричневых почв на двух участках Абраусского полуострова. Основной упор сделан на исследование мониторинговой площадки Водопадной щели заповедника «Утриш», расположенной на постпирогенном участке можжевелового редколесья на высоте 110-140 м н.у.м. на южных отрогах хребта Навагир. Пожар случился в 2009 г. Дополнительно в апреле 2018 г. был исследован участок пожарища 2013 г. в непосредственной близости от Сухой щели заповедника «Утриш». Площадь пожарищ с нарушением наземной растительности и изменением экологического состояния почв составляет несколько гектар. Показано, что на большей части Абраусского полуострова, включая природный заповедник «Утриш», распространены редкие для России коричневые почвы (Cromic Cambisol и Cromi-Leptic Luvisol по международной классификации WRB). Главными признаками коричневых почв являются: коричневый цвет профиля, интенсивное текстурное оглинивание средней части профиля почвы, элювиально-иллювиальный тип декарбонизации, близкая к нейтральной реакция среды, богатство почвы элементами минерального питания. Особенности исследованных почв заповедника «Утриш», обусловленные низкогорным рассеченным рельефом территории, - это более короткий почвенный профиль, высокая каменистость и щебенчатость, отсутствие карбонатных новообразований, фрагментарность и маломощность лесной подстилки. Исследования эколого-биологических свойств почв (температуры, влажности, плотности почв, содержание гумуса и карбонатов, численности бактерий, активности ферментов каталазы, пероксидазы, дегидрогеназ, инвертазы и др.) проводили по общепринятым методам. Показано развитие восстановительной сукцессии в травянисто-кустарниковой стадии на обоих пожарищах. Установлено значительное влияние пожаров на эколого-биологические свойства коричневых почв. Спустя 5-9 лет после пожара многие биологические свойства постпирогенных почв значительно различаются по сравнению со свойствами контрольных участков можжевелового редколесья. Содержание гумуса и биологическая активность постпирогенных почв, в целом, снижены по сравнению с почвами контрольных участков можжевелового редколесья. При этом было отмечено высокое варьирование биологических показателей почв на разных участках одного пожарища. Варьирование связано как с особенностями горного рельефа, так и с характером растительности, образующей разные по количеству растительных остатков рефугиумы. Интенсивность продуцирования углекислого газа в поверхностных горизонтах почв пожарища более чем в 2 раза ниже по сравнению с контрольными значениями. Постпирогенная почва участка Сухой щели, спустя 5 лет после пожара, содержит почти вдвое меньшее содержание гумуса в поверхностном пятисантиметровом слое по сравнению с почвой контрольного участка можжевелового редколесья. На глубине 15-25 см различие между почвами участками сохраняются на том же уровне, что и для верхних горизонтов. Таким образом показано значительный эффект пожаров на биологические параметры субтропических почв заповедника «Утриш», сохраняющийся в течение многих лет.

Ключевые слова: биологическая активность, гумус, пирогенное воздействие, пожары, почвенные ферменты 